\author{
KRYSTYNA ROMANISZYN \\ UNIWERSYTET JAGIELLOŃSKI \\ E-MAIL: USROMANI@CYF-KR.EDU.PL
}

\title{
CZYNNIKI POTENCJALNEJ DEKONSTRUKCJI POGRANICZA ETNICZNEGO
}

\section{Wprowadzenie}

Problematyka granic(y), chociaż często inaczej identyfikowana, jest w socjologii i antropologii obecna od dawna w kontekstach dotyczących: dystynkcji, podziałów, granic społecznych i granic pomiędzy grupami społecznymi. Można ją odnaleźć między innymi w pracach klasyków: Williama Grahama Sumnera [1995: 15 i nast.] - chodzi o rozróżnienie między grupą-my (we-group) i grupą-oni (other-group) czy Georga Simmla [1975] - chodzi o kategorię „obcego”. Współcześnie problematyka granic(y) została w antropologii mocniej wyeksponowana przy walnym udziale pracy Fredrika Barth'a zatytułowanej Ethnic Groups and Boundaries [1999]. Jednym wyraźnie wyodrębniającym się nurtem są w antropologii społecznej badania dotyczące granic społecznych, drugim są badania poświęcone „społecznościom żyjącym na lub w pobliżu granic między państwami”, które to granice również można uznać za „przypadek szczególny granic społecznych" [Lubaś 2011: 111]. W polskiej socjologii i antropologii również rozwijają się zarówno badania nad społecznościami żyjącymi w pobliżu granic państwowych, jak i badania poświęcone, różnie nazywanej, społecznej przestrzeni kontaktu między różnymi grupami etnicznymi. Część tych badań buduje zasoby powstałej socjologii pogranicza.

Bez wątpienia samo pojęcie pogranicza oraz rozwijająca się socjologia pogranicza otwierają cenną i wartą dalszego rozwoju perspektywę badawczą, szczególnie przydatną do badania ciągłości i zmiany czy szerzej trwania i przeobrażeń społeczno-kulturowych w skali lokalnej, czyli w skali mikrosystemu - szczególnego, bo stanowionego przez przedstawicieli (nosicie- 
li) więcej niż jednej kultury. Z tego też powodu konieczna jest szczególna dbałość o utrzymanie wyraźnie określonego pola semantycznego pojęcia pogranicze. Odwołując się do metafory można powiedzieć, że konieczne jest omijanie Scylli rozszerzania zakresu pojęcia pogranicze, aż do jego rozmycia i tym samym do pozbawienia go wartości jako kategorii analitycznej w badaniach empirycznych. Konieczne jest też omijanie Charybdy tak restrykcyjnego zawężenia zakresu semantycznego omawianego pojęcia, że stanie się ono mało przydatne w badaniach zmieniającej się rzeczywistości społeczno-kulturowej. Wydaje się jednak, że obecnie większe jest zagrożenie ze strony wyżej wskazanej Scylli. W różnych bowiem kontekstach stale pojawia się teza, że wszyscy mieszkamy dziś na pograniczu. Tak radykalne rozszerzenie zakresu semantycznego pojęcia pogranicze oznacza wprost jego rozmycie. Oznacza także mieszanie, niekoniecznie celowe, pojęć: pogranicze i granice społeczne.

\section{Pogranicze}

W odwołaniu do literatury przedmiotu trzeba powiedzieć, że pojęcie pogranicza odnosi się do konkretnego obszaru (przestrzeni), „na którym występują trwałe formy kontaktów społeczno-kulturowych zachodzących między dwoma lub więcej sąsiednimi narodami, mniejszościami narodowymi lub grupami etnicznymi. (...) Cechą charakterystyczną pogranicz etnicznych są różne postacie kontaktów kulturowych" [Sadowski 2001: 11]. Rezultatem owych stałych kontaktów jest stworzenie kultury będącej strefą buforową między narodami czy grupami etnicznymi [Sadowski 2001: 16]. Z przedstawionej definicji pogranicza wynika, że cechami konstytutywnymi rzeczywistości nazywanej pograniczem są:

a) konkretny, wyraźnie określony obszar;

b) sąsiedztwo ${ }^{1}$, czyli nie tylko wspólne zamieszkiwanie danego obszaru, lecz przede wszystkim powstanie i trwanie relacji czy też kontaktów społeczno-kultowych pomiędzy jego mieszkańcami;

c) długi okres wspólnego zamieszkiwania danego obszaru i trwania wzajemnych kontaktów;

d) powstanie specyficznej lokalnej kultury jako rezultatu owych (długo) trwałych interakcji.

Na fakt sąsiedztwa, chociaż innymi słowami, zwraca uwagę także Ewa Nowicka pisząc, że pogranicze jest obszarem, na którym w bezpośrednim kontakcie żyją przedstawiciele różnych, co najmniej dwóch, kultur bądź grup etnicznych [Nowicka 1999: 13]. 
Pogranicze jest zatem etnokulturową przestrzenią, na której historycznie współistnieją dwie lub więcej grupy etnokulturowe [Sadowski 1992: 5-6]. Zgodnie z przedstawioną definicją pod pojęciem pogranicza należy rozumieć historyczne pogranicze etniczne. Tak też pojęcie to rozumiem.

Przestrzeń pogranicza zamieszkują ludzie określonego typu. Przynależą oni do kilku kultur [Sadowski 1992: 5-6] i są nosicielami, przede wszystkim, lokalnej tożsamości [Sadowski 2001: 16]. Jest to lokalna tożsamość zbiorowa (kolektywna). Wyraża się ona w powstałej kulturze pogranicza. Ujmując rzecz inaczej, można powiedzieć, że nie co innego, jak właśnie wytworzenie kultury (danego) pogranicza dowodzi istnienia na tym obszarze lokalnej tożsamości zbiorowej (kolektywnej). Cechy kultury pogranicza są bowiem zarazem cechami kolektywnej tożsamości jego mieszkańców. Kultura pogranicza, w której i przez którą wyraża się lokalna tożsamość zbiorowa, stanowi też podstawę specyficznej tożsamości jednostkowej jego mieszkańców. Ostatecznie, bez lokalnej kultury - rezultatu historycznej obecności na obszarze pogranicza kilku kultur i stałej interakcji ich przedstawicieli, bez wyrażającej się w tej kulturze i poprzez nią tożsamości zbiorowej i bez budowanej na tej kanwie specyficznej tożsamości jednostkowej nie ma pogranicza, są tylko tereny przygraniczne. W przedstawionych ustaleniach definicyjnych historyczność, czyli trwanie i rozwój w czasie stanowi bardzo ważny wyróżnik pogranicza. Z historycznością wiąże się, oczywiście, kwestia dziejów danego pogranicza, i to zarówno dziejów politycznych, jak i historii codziennej, społecznej i ekonomicznej². Dzieje obszaru pogranicza wespół z powstałą na nim kulturą i tożsamością zbiorową, która stanowi matrycę dla tożsamości jednostkowej stanowią łącznie o istocie czy specyfice danego pogranicza.

W szystkie wskazane cechy konstytutywne pogranicza, czyli jego kultura, tożsamość zbiorowa, tożsamość jednostkowa mieszkańców obszaru pogranicza oraz jego historyczność bronią przed nadmiernym rozszerzeniem pola semantycznego omawianego pojęcia. Pozwalają też wyraźnie odróżnić pogranicze od terenów przygranicznych nazywanych niekiedy pograniczem międzypaństwowym ${ }^{3}$. Utożsamianiu pogranicza i terenów przygranicznych sprzyjają przynajmniej dwie okoliczności. Pierwszą, jest usytuowanie pogranicza w pobliżu granic państwowych. Pogranicze bowiem „to każdy obszar

2 O tym, że historia pogranicza - nie tyle polityczna, ile codzienna, społeczna i ekonomiczna - stanowi o jego istocie, pisze G. Babiński [1997: 44].

3 Na fakt nietożsamości pogranicza etnokulturowego z pograniczem międzypaństwowym zwracał uwagę A. Sadowski [1992: 6]. 
ulokowany $\mathrm{w}$ pobliżu dawniejszych lub obecnych granic politycznych, w przeszłości czy współcześnie nimi przeciętych" [Szczepański 2001:36-37]. Drugą okolicznością sprzyjającą utożsamianiu pogranicza z terenami przygranicznymi jest jego peryferyjność wobec centrów polityczno-administracyjnych oraz zmienna przynależność państwowa i administracyjna, skutkująca narodową labilnością mieszkańców pogranicza [Szczepański, 2001: 36-37] ${ }^{4}$. Przedstawiona wyżej definicja pogranicza daje możliwość uniknięcia uproszczenia, którym jest utożsamianie pogranicza i terenów przygranicznych, pozwala też zachować rozłączność obydwu pojęćs. To z kolei umożliwia śledzenie i analizę procesu przekształcania się terenów przygranicznych w pogranicze, tam gdzie toczy się on wprost na naszych oczach. Obecnie takim obszarem - a dla badaczy naturalnym laboratorium - na którym być może toczy się proces powstawania pogranicza są tereny przy granicy polsko-niemieckiej, powstałej w rezultacie powojennego przesuwania granic państw. W ostatnich dekadach miejsce to staje się widownią nawarstwiania i przenikania się rozmaitych wpływów przyniesionych przez osiadłe tu odmienne grupy etnicznie [Kurzępa 2001: 336]. Może to być pierwszy krok do powstania pogranicza, rozumianego jako historyczne pogranicze etniczne.

Podsumowując przedstawiony wywód należy stwierdzić, że pogranicze formują i charakteryzują: dzieje trwałych kontaktów międzykulturowych zapośredniczonych przez relacje między nosicielami tych kultur wspólnie zasiedlającymi jeden obszar oraz powstałe w toku owych trwałych relacji: specyficzna kultura zakorzeniona na tymże terytorium, tożsamość zbiorowa (kolektywna) i tożsamość jednostkowa mieszkańców rzeczonego obszaru. Jest to historyczne pogranicze etniczne. Jest ono rodzajem mikrosystemu społecznego przez lata budowanego przez kilka kultur, będę je dalej nazywała pograniczem właściwym.

Historyczność pogranicza etnicznego wymaga przyjęcia w poświęconych mu badaniach długiej perspektywy czasowej. Wypracowane w toku takich badań rozstrzygnięcia metodologiczne i podejścia teoretyczne sprawiają z kolei, że socjologia pogranicza współtworzy socjologię historyczną rozumianą nie jako (nowa) poddyscyplinę socjologiczną, lecz jako orientację

Autor wskazuje również na już nazwaną cechę pogranicza, czyli na to, że regionalny układ kultury jest wynikiem wieloletniego przenikania się kultur i tradycji.

5 Ułatwia także rozróżnianie zjawisk zachodzących na pograniczu od zjawisk i działań mających miejsce na terenach przygranicznych, takich jak: niekoncesjonowany handel, wyprawy za granicę po zakupy lub wyprawy do placówek kulturalnych - muzeum, teatru, filharmonii. 
teoretyczno-metodologiczną ${ }^{6}$. Filarem badań pogranicza podejmowanych w długiej perspektywie czasowej jest przedstawiona definicja pogranicza pojmowana jako jego typ idealny. Idealnotypologiczne ujmowanie definicji pogranicza (właściwego) wyposaża badacza w narzędzie: analizy konkretnych przypadków pogranicza, analizy porównawczej różnych przypadków pogranicza właściwego, oraz wstępne bodaj, w narzędzie badania zmiany zachodzącej w czasie na danym pograniczu.

Zmiana wydaje się wpisana $\mathrm{w}$ mikrosystem pogranicza budowany przez relacje mieszkańców pogranicza, nosicieli jego kultur. Może ona dotyczyć wzorów myślenia, zachowań i działania ludzi, relacji między nimi, sposobu organizacji społecznej ${ }^{7}$, czyli różnych aspektów kultury pogranicza. Badanie dynamiki kultury pogranicza wpisuje się z kolei w socjologię zmiany społecznej stając się przyczynkiem do niej. Socjologia zmiany społecznej zyskuje $\mathrm{w}$ ten sposób wartościowe i naturalne laboratorium badawcze pozwalające na obserwację mechanizmów i skutków zmiany powodowanej w kulturze pogranicza zarówno przez czynniki wewnętrzne, jak i zewnętrzne - ogólnosystemowe, regionalne czy wręcz globalne. Wyliczone wyżej wymiary czy aspekty kultury pogranicza, to zarazem problemy bądź tematy dla badań zmiany kultury pogranicza. Odsyłają też do kwestii granic społecznych na pograniczu właściwym.

\section{Pogranicze a granice społeczne}

Granice społeczne to „społeczne ograniczenia lub zakazy nałożone na określone formy kontaktów i współdziałania”, co więcej granice społeczne nie rozgraniczają obszarów, lecz stanowią barierę „utrudniającą lub uniemożliwiającą specyficzne kontakty między pewnymi kategoriami osób”, można powiedzieć, że "granice społeczne porządkują życie społeczne, a dokładniej są jednym z aspektów porządku społecznego" [Lubaś 2011: 115]. Z ustaleń tych wynika, że granice społeczne stanowią bardzo ważny aspekt porządku społecznego w ogóle, w tym także w mikrosystemie pogranicza. Nieodzownym zatem elementem badań pogranicza jest opis i interpretacja typowych dla niego granic społecznych, rozumianych jak wyżej, czyli jako przyjęte, i ulegające zmianom w czasie, społeczne ograniczenia i nakazy nałożone na różne postaci kontaktów i współdziałania mieszkań-

6 Na temat socjologii historycznej pojmowanej nie jako kolejna subdyscyplina socjologiczna, lecz jako nowa orientacja teoretyczno-metodologiczna możliwa do zastosowania w badaniu każdego socjologicznego wątku pisze P. Sztompka [1991].

7 O sposobie definiowana zmiany społecznej pisze między innymi P. Sztompka [2005: 20 i nast.]. 
ców społeczności pogranicza. Badanie przemian społecznych ograniczeń i nakazów, czyli przemian w obrębie granic społecznych jest na pograniczu etnicznym (właściwym) szczególnie ważne, ponieważ dotyczy (potencjalnej) dynamiki kontaktów międzykulturowych właściwych pograniczu.

Zakresy semantyczne pojęć pogranicze właściwe i granice społeczne, pojmowane jako element porządkujący życie społeczne, pozostają oczywiście rozłączne. Jednocześnie z definicji granic społecznych wynika, że konieczne jest badanie granic społecznych także w społeczności pogranicza. Może to rodzić niebezpieczeństwo mieszania obydwu pojęć. Kontekstem szczególnie sprzyjającym takiemu mieszaniu jest sytuacja wielokulturowości całego społeczeństwa powodowana bądź utrwalana przez narastające, a nie malejące masowe, globalne imigracje osiedleńcze. Zetknięcie kultur ${ }^{8}$ mające miejsce w warunkach wielokulturowości społeczeństwa przyjmującego może skłaniać do identyfikowania społecznych przestrzeni tegoż zetknięcia i powstających w niej granic społecznych z pograniczem. Tym bardziej, że wielokulturowość społeczeństwa, jako rzeczywistość złożona i zmienna, stale wymyka się zadowalającej interpretacji. Jednak nazywanie społecznych przestrzeni kontaktu - mających miejsce w warunkach wielokulturowości - wraz z powstającymi w nich granicami społecznymi pograniczem prowadzi do wskazanego uprzednio zagrożenia dekonstrukcji (rozmycia) pojęcia pogranicze. Zagrożenie to pomniejsza, lecz go nie niweluje nazywanie społecznych przestrzeni kontaktu pograniczem kulturowym.

Zbliżoną do wskazanej formą nadmiernego rozszerzania pojęcia pogranicze są badania, w których to pojęcie - i perspektywa badawcza, którą ono otwiera - służy wprost do nazywania i opisywania granic społecznych i granic symbolicznych cechujących koegzystencję różnych grup etnicznych czy religijnych w ramach jednego systemu społeczno-kulturowego. W tym kontekście trzeba wskazać na zagrożenie wynikające $\mathrm{z}$ uznania pojęcia granica za podstawową i konstytutywną cechę pogranicza przy jednoczesnym braku jego zdefiniowania. W sytuacji identyfikowania $\mathrm{w}$ antropologii społecznej i socjologii różnego rodzaju granic może to prowadzić

8 Celowo stosuję określenie zetknięcie kultur, a nie kontakt międzykulturowy. To ostatnie rezerwuję wyłącznie do sytuacji rzeczywistych kontaktów podjętych i podtrzymywanych przez nosicieli odrębnych kultur. Stosując wskazane rozróżnienie chcę podkreślić, że spowodowane przez masową imigrację zetknięcie się przedstawicieli różnych kultur w ramach jednego społeczeństwa nie musi prowadzić i niejednokrotnie nie prowadzi do kontaktów międzykulturowych, będąc wyłącznie zetknięciem się wymuszonym przez okoliczności. 
do nazywania jednym i tym samym pojęciem różnych jakościowo zjawisk czy faktów ${ }^{9}$. Wobec rosnącej w socjologii popularności terminu granica, na podkreślenie zasługuje i to, że już sam ten termin budzi skojarzenie z linią, a nie „Z obszarem, zoną” [Lubaś 2011: 105], stanowiącą jeden z konstytutywnych elementów pogranicza.

Formą kłopotliwego - z racji poznawczych - rozszerzania pola semantycznego pojęcia pogranicze jest także objęcie nim całego regionu czy części kontynentu, jak w przypadku uznania całej Europy Środkowo-Wschodniej za pogranicze wyznaniowe (religijne), ściślej za pogranicze katolicko-prawosławne i chrześcijańsko-islamskie [Zenderowski 2012: 121] ${ }^{10}$, czyli za obszar, na którym dochodzi do zetnicyzowania religii. Takie rozszerzenie czyni pojęcie pogranicze kategorią opisową odbierając jej de facto walor kategorii analitycznej. Pewne konfuzje powoduje także wyróżnianie faz przemian pogranicza połączone $\mathrm{z}$ brakiem doprecyzowania tegoż pojęcia. Gdy, w takiej sytuacji, mowa jest na przykład o pograniczu przednowoczesnym, nowoczesnym i ponowoczesnym [Krzysztofek 2001: 33-34], pojawia się potrzeba dopowiedzenia: czy chodzi o ewolucję (jednego i tego samego) pogranicza czy o typy pogranicz występujące symultanicznie.

W świetle powyższych stwierdzeń nie wymaga dowodu i dalszego uzasadnienia celowość i użyteczność - dla rozwoju warstwy teoretycznej socjologii pogranicza, a także dla badań empirycznych $\mathrm{z}$ tego zakresu - nierozszerzania pola semantycznego pojęcia pogranicze i utrzymania jego przyjętej definicji. Czyli, zarezerwowanie omawianego terminu dla nazywania obszaru będącego historycznym pograniczem etnicznym, społeczności zamieszkującej ów teren i wytwarzanej przez nią kultury.

Jak z powyższego wynika, pierwszy czynnik potencjalnej, wzmiankowanej w tytule, dekonstrukcji pogranicza jest natury metodologicznej. Dotyczy on Scylli rozszerzania zakresu semantycznego pojęcia pogranicze, aż do rozmycia tegoż pojęcia i pozbawienia go wartości jako kategorii analitycznej w badaniach empirycznych. Obok wskazanego rysują się także zagrożenia wynikające z przeobrażeń współczesnego świata. Niektóre z nich wskazuję i omawiam poniżej.

9 Tytułem przykładu można wskazać na stwierdzenia, „ponieważ pogranicze jest korelatem granicy, więc zmieniająca się natura granic musi odmieniać także pogranicza” oraz „historyczne pogranicza etniczne utraciły już dawno monopol na bycie pograniczami” [Krzysztofek 2001: 25, 32].

10 Dalej czytamy: „religia nie jest (i nie była) w Europie Środkowo-Wschodniej ani sprawą prywatną (chodzi przecież o naród i jego istnienie), ani tym bardziej - obojętną". 


\section{Potencjalne czynniki dekonstrukcji pogranicza właściwego}

Współcześnie w dobie globalizacji, przede wszystkim globalizacji kulturowej wraz z niepoślednią w niej rolą mediów, a także rewolucji technologicznej konieczne staje się badanie wpływu, jaki te fakty i procesy wywierają na mikrosystem pogranicza właściwego i na zachodzące w nim przemiany. W omawianym kontekście na osobną wzmiankę zasługuje kwestia euroregionów w pierwszym rzędzie związana $\mathrm{z}$ integracją europejską, a szerzej z globalizacją. Euroregiony to wyodrębnione obszary współpracy przygranicznej powstające w myśl przyjętych unijnych ustaleń i wytycznych, które to reguły działania kodyfikowane są w różnych dokumentach prawnych, między innymi w Kartach Samorządu Terytorialnego, czy Kartach Samorządu Regionalnego. Celem euroregionów jest integracja obszarów przygranicznych. Tworzone na historycznym pograniczu etnicznym lub na części takiego obszaru są, niezależnie od intencji, rodzajem zewnętrznej ingerencji w mikrosystem pogranicza. Jej długookresowe skutki nie są łatwe do przewidzenia, nie można jednak wykluczyć, że euroregiony powstające na historycznym pograniczu etnicznym lub w poprzek niego okażą się wstępem do jego dekonstrukcji, na przykład w skutek stopniowej unifikacji grup etnokulturowych, których koegzystencja i stały kontakt buduje etnokulturę pogranicza, a tym samym je same. Badanie rodzaju i skutków oddziaływania euroregionu powstałego na obszarze lub na części obszaru pogranicza właściwego stanowi jedno z zadań stojących przed socjologią pogranicza.

Czynnikami potencjalnej dekonstrukcji historycznego pogranicza etnicznego, na które pragnę zwrócić uwagę są ponadto:

- uniformizacja kultur jako rezultat globalizacji kulturowej;

- wielokulturowość jako rezultat masowych migracji osiedleńczych;

- emigracja z obszarów pogranicza jako terenu peryferyjnego; oraz

- cichy demontaż państw narodowych.

Globalizacja kulturowa, jeden z wyróżników współczesnego świata, stanowi podstawowy czynnik postępującej unifikacji kultur (systemów społeczno-kulturowych) ${ }^{11}$. Konieczne jest zatem badanie przejawów i skutków globalizacji kulturowej w mikrosystemie historycznego pogranicza i jego etnokultury. Uściślając, w pierwszym rzędzie chodzi o rozpoznawanie

11 Odwołuję się do antropologicznego pojmowania kultury jako rzeczywistości zarazem kulturowej i społecznej, przy założeniu ich zasadniczej jedności i rozróżnianiu tylko na potrzeby analizy [Kłoskowska 1983: 20, 25; Turowski 1994: 67]. 
wpływu transmitowanej za pośrednictwem (różnorakich) środków masowego przekazu globalnej kultury popularnej, jako rezultatu stale rozwijającego się „przemysłu kulturowego” - by posłużyć się określeniem Maxa Horkheimera. Rozwijające się „przemysł kulturowy”, a w jego ramach przemysły medialno-rozrywkowy i reklamowy systematycznie anektują kolejne społeczeństwa, społeczności i ich kultury przez zarzucanie ich rosnącą masą swoich produktów niematerialnych ${ }^{12}$. W rezultacie aneksji kolejnych kultur postępującej wraz z globalną ekspansją owych „przemysłów” i ich produktów odbiorcy i konsumenci podsuwanych ofert czy, innymi słowy, konsumenci globalnie transmitowanej kultury popularnej upodabniają się do siebie w swoich zachowaniach, upodobaniach, wyglądzie, wyborach etc., niekoniecznie w sposób dla siebie zauważalny. Oczywiście, mieszkańcy historycznego etnicznego pogranicza nie pozostają poza zasięgiem tego oddziaływania ${ }^{13}$. Podobnie jak pozostali mieszkańcy danego kraju podlegają oni tym samym ujednolicającym imperatywom propagowanych wzorów zachowania, działania, myślenia, reagowania, samookreślania się przedstawianych jako nowoczesne, „na topie”, „cool” czy jakkolwiek inaczej ${ }^{14}$. Następstwem unifikującego wpływu globalnie transmitowanej kultury popularnej na kolejne kultury i jej nosicieli konsumujących oferowane im produkty jest zacieranie się różnic między „domem” (home) i „zagranicą” $(\text { abroad })^{15}$. Tak urzeczywistnia się uniformizacja kolejnych kultur (systemów społeczno-kulturowych). Wpływ ten może być silniejszy właśnie na obszarze pogranicza, $\mathrm{z}$ definicji peryferyjnym wobec administracyjno-polityczno-gospodarczego centrum i kompensującego swą peryferyjność przez tym pilniejsze naśladowanie i przejmowanie wszelkich wzorów $\mathrm{Z}$,wielkiego świata”. Co więcej, wpływ ten może być silniejszy na pograniczach krajów słabiej rozwiniętych, zatem także i Polski ${ }^{16}$. Większa odporność krajów za-

12 Dobra (towary) niematerialne to określenie Benjamina Barbera [1997].

13 Kazimierz Krzysztofek [2001: 28] ujął to następująco: „niezależnie od grupy etnicznej wszyscy konsumują tę samą kulturę, są uczestnikami tej samej kultury popularnej”. Można to wyrazić w następujących słowach: „individual human beings are everywhere equal, everywhere activated by the globalizing imperatives of self-rule and agency" [Haigh 2013: 198].

15 Jak czytamy: „under globalizing conditions, «abroad» now shares essential characteristics with, and is largerly inseparable from home", czyli "home and abroad share the same essence" [Haigh 2013: 198]. Wprawdzie sam autor nie precyzuje, jaki aspekt procesu globalizacji ma tu na myśli; wydaje się jednak, że obserwacja dotyczy przede wszystkim rezultatów globalizacji kulturowej.

16 Odwołuję się do stwierdzenia dotyczącego skuteczności amerykanizacji poprzez globalny przemysł kultury popularnej; jak uważam można je także odnieść do globalizacji kulturowej w ogóle i do mikrosystemu pogranicz(a) krajów słabiej rozwiniętych: „developed countries are better equipped to counter the (allegedly) deleterious effects of the cultural hegemon, whereas underdeveloped countries risk getting thoroughly swamped" [Haigh 2013: 206]. Autor nie podaje przyczyn stwierdzanego stanu rzeczy. 
możnych na unifikujący wpływ globalnej kultury popularnej to nie tylko pochodna zasobów pozwalających na wspieranie rodzimej kultury, w tym kultury wysokiej, na jej dostępność (także finansową) i na jej popularyzowanie w społeczeństwie, lecz i pochodna umiejętnie pielęgnowanego w społeczeństwie wysokiego mniemania o wyższości i wartości własnej kultury. I przeciwnie, cechą krajów niezamożnych i peryferyjnych jest przekonanie o niższości i bezwartościowości własnej kultury oraz pielęgnowanie tego przekonania, wyraźnie dostrzegalne także w Polsce. Niebagatelnym, wobec tego, zadaniem socjologii pogranicza jest śledzenie przebiegu uniformizacji powodowanej przez globalnie transmitowane produkty przemysłu kulturowego, wraz z jego przybudówkami, czyli przemysłami inforozrywkowym i reklamowym, w mikrosystemie historycznego pogranicza i badanie wpływu, jaki wywiera ona na specyficzną, dotąd, etnokulturę tego obszaru. W badaniach takich wyjściowym są pytania o to czy i jak możliwe jest trwanie etnokultury pogranicza w świecie uniformizowania kultur (systemów społecznokulturowych) zapośredniczonego przez globalizację kulturową? I oto czy i jak w takim kontekście możliwe jest budowanie etnokultury na terenach przygranicznych (na przykład przy granicy polsko-niemieckiej)? Są to pytania fundamentalne, ponieważ zgodnie z przyjętą definicją, pogranicze nie istnieje bez właściwej mu etnokultury. Dekonstrukcja etnokultury pogranicza bądź niemożność jej zaistnienia na terenach przygranicznych oznacza w dłuższej lub krótszej perspektywie zanik pogranicza właściwego. Ewentualność taka jest tym bardziej realna, że zniszczenie etnokultury pogranicza nie wymaga tak długiego czasu jak jej powstanie. Ponadto, na niebywałą skuteczność procesu uniformizacji duży wpływ ma jego niejawność i niegwałtowność. Badanie procesu dekonstrukcji etnokultury pogranicza jako rezultatu globalizacji kulturowej wymaga wyodrębnienia i nazwania wymiarów (aspektów) tejże etnokultury i śledzenia zmian, jakim one podlegają.

Czynnikiem, który towarzyszy uniformizacji kultur powodowanej przez globalną transmisję i konsumpcję produktów przemysłu kulturowego jest konsumpcjonizm, oddziałujący na kultury w podobny homogenizujący sposób ${ }^{17}$. Idąc $\mathrm{w}$ parze $\mathrm{z}$ zaszczepianym $\mathrm{w}$ kolejnych społeczeństwach etosem infantylizmu ${ }^{18}$ formuje $\mathrm{w}$ nich taką samą osobowość podstawową, czyli narcystycznych, żyjących wiecznym "teraz”, skoncentrowanych na

17 Obszernie omawiam ten problem w innym miejscu [Romaniszyn 2015; 2007].

18 O etosie infantylizmu pisze i objaśnia go B. Barber [2008]. 
swoim „ja” zinfantylizowanych konsumentów dostarczanych im towarów, usług, wrażeń. W ten sposób oddolnie, bo przez formowanie osobowości podstawowej postępuje ujednolicanie społeczeństw. Kolejnym pytaniem badawczym jest, zatem czy i jak ów proces przebiega $\mathrm{w}$ mikrokosmosie etnokultury pogranicza przekształcając jego mieszkańców w infantylnych konsumentów produktów globalnego przemysłu kulturowego?

Następnym z wymienionych uprzednio czynników potencjalnej dekonstrukcji pogranicza właściwego jest lub może być wielokulturowość jako rezultat masowej imigracji osiedleńczej w danym społeczeństwie (kulturze). Wielokulturowość, o której mowa oznacza zetknięcie się przedstawicieli różnych, często odległych sobie kultur w ramach społeczeństwa przyjmującego. W Europie w nieodosobnionych przypadkach owo zetknięcie przekształca się w zderzenie kultur. Jego wyrazem szczególnie istotnym dla omawianej tu kwestii jest powstawanie zamkniętych na kulturę kraju osiedlenia enklaw etnicznych tworzonych przez imigrantów i rządzących się swoimi własnymi prawami nawet, gdy pozostają one w niezgodzie z prawem tegoż kraju. Ewentualne powstanie takiej enklawy na obszarze pogranicza właściwego stałoby się imputowanym mu, czyli zewnętrznym czynnikiem zmiany. Wielokulturowość społeczeństwa (systemu społecznokulturowego) powstała wskutek imigracji, wraz z ideologią i polityką intensywnego wspierania różnorodności kulturowej systemu ${ }^{19}$, ma stać się tyglem do przetapiania wepchniętych weń kultur. Problemem badawczym jest to, czy tygiel wielkokulturowości mający przetapiać wrzucone weń kultury objął już konkretne pogranicza (właściwe) i jaki jest tego rezultat.

Właśnie w kontekście wielokulturowości powstałej w rezultacie masowego napływu i osiedlenia przedstawicieli odległych kultur w danym systemie społecznokulturowym pojawia się propozycja identyfikowania nowych postaci pogranicza [Babiński 2001; Krzysztofek 2001: 25 i nast.]. Pojmowane jako obszary koegzystowania różnych kultur, często na obrzeżach lub w sąsiedztwie wielkich metropolii, owe „nowe pogranicza” są skutkiem wielokulturowości, jako faktu, polityki i ideologii. Zaistniały one w rezultacie: zgody na masową imigrację przedstawicieli odległych kultur, zgody na podtrzymywanie przez nich własnej, odrębnej kultury, a także zgody na finansowe wspieranie tej odrębności kulturowej. Od pogranicza właściwego „nowe pogranicza” odróżniają zarówno nie-historyczność, jak i egzy-

19 Nie ulega wątpliwości, że „ostatnie dwie dekady w demokratycznych państwach wielokulturowych: USA, Kanadzie, Australii, w mniejszym stopniu zachodniej Europie, upływały pod znakiem politycznie poprawnej batalii o maksymalizację różnorodności” [Krzysztofek 2001: 30]. 
stowanie na danym terenie nosicieli różnych kultur vis-a-vis siebie, czyli bez podejmowania trwałych lub jakichkolwiek relacji. To sprawia, że w nieodosobnionych przypadkach trafniejsze wydaje się nie tyle identyfikowanie nowych pogranicz $\mathrm{w}$ interiorze społeczeństwa przyjmującego, ile sąsiadujących z sobą, niekiedy dość hermetycznych enklaw kulturowych budowanych przez przybyszów. Wśród ich mieszkańców utrwala się tożsamość etniczna, i to nie tylko w trzecim pokoleniu jak głosi słynne prawo Hansena, a wraz z nią „pojawia się potrzeba reterytorializacji własnych symboli w obcej kulturowo przestrzeni" [Krzysztofek 2001: 26], co tylko utrwala enklawę. Trwanie zaś enklaw imigrantów, utrzymywanie i umacnianie się poczucia odrębności wśród ich mieszkańców oraz budowanie przez nich tożsamości w opozycji do bezpośrednich sąsiadów i do społeczeństwa przyjmującego skłaniają do stwierdzenia, że orzekane przez Samuela Huntinghtona zderzenie cywilizacji ma już miejsce i dochodzi do niego w obrębie społeczeństw wielokulturowych. Włączanie do opisu i interpretacji tych zjawisk pojęcia pogranicze przy jednoczesnym nadawaniu mu nowego znaczenia wzbogaci być może studia nad wielokulturowością. Za cenę rozszerzenia pola semantycznego pojęcia pogranicze. Nie wydaje się to służyć socjologii pogranicza. Właśnie w kontekście badań wielokulturowości przy zastosowaniu pojęcia pogranicze konieczne jest szczególnie uważne żeglowanie między Scyllą rozmycia tego pojęcia a Charybdą jego restrykcyjnego pojmowania.

Kolejnym zagrożeniem dla pogranicza właściwego (historycznego pogranicza etnicznego) związanym z mobilnością przestrzenną jest masowa emigracja $\mathrm{z}$ jego terenów prowadząca do stopniowego wyludniania się tego obszaru. Mowa tu nie o exodusie wywołanym przez czynniki polityczne, lecz o masowej emigracji w czasie pokoju powodowanej przez względy ekonomiczne. Tymi ostatnimi bywają pospołu brak pracy lub pracy za zadowalające wynagrodzenie i na zadowalających warunkach oraz wzrost potrzeb i aspiracji konsumpcyjnych ${ }^{20}$. O realności wyludniania się pogranicza wskutek emigracji o charakterze ekonomicznym wskazuje współczesny przykład pogranicza usytuowanego na Podlasiu ${ }^{21}$. Powodowane przez emigrację ekonomiczną wyludnianie się pogranicza połączone z unifikującym wpływem transmitowanej globalnie kultury popularnej, homogenizującym etnokulturowe grupy pogranicza i ich nosicieli, prowadzi do jego dekon-

20 Obszernie piszę na ten temat w innym miejscu [Romaniszyn 2007].

21 Na temat wyludniania się Podlasia wskutek migracji można między innymi przeczytać w książce pod redakcją M. Wieruszewskiej [2007]. 
strukcji drogą prostą, szybką i pokojową. Jest to też kolejny z wyróżnianych tu problemów badawczych socjologii pogranicza.

$\mathrm{Na}$ koniec warto zwrócić uwagę na jeszcze jeden możliwy czynnik dekonstrukcji pogranicza właściwego, jakim jest cichy demontaż państw narodowych. Obecnie dokonuje się on, niejawnie, przede wszystkim za pośrednictwem globalizacji ekonomicznej budującej potęgę finansową ponadnarodowych i antynarodowych koncernów i korporacji, w rosnącym stopniu przewyższającą siły i władzę ekonomiczną kolejnych państw narodowych. Faktom tym i poczynaniom towarzyszy praca akademii wskazująca na rzekomy zmierzch ery westfalskiej i roztaczająca wizję nowego ładu światowego bez państw narodowych lub też nowej ery post-westfalskiej $\mathrm{z}$ odmiennym typem państwa. $\mathrm{W}$ jednej $\mathrm{z}$ takich, nowszych, prób dowiadujemy się, że tradycyjne i statyczne państwo ery westfalskiej (często) zdominowane przez antydemokratyczne i antyuniwersalistyczne sentymenty i impulsy ustępuje miejsca swojemu przeciwieństwu nazwanemu „zaawan-

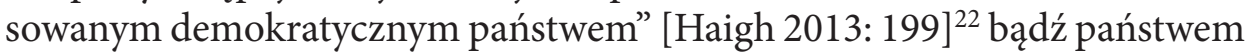
kosmopolitycznym. Właśnie te ostatnie mają tworzyć nowy, globalny neofeudalny porządek nazwany przez autora „neośredniowiecznym porządkiem zakorzenionych kosmopolitycznych państw" (neo-medieval order of embedded cosmopolitical states), [Haigh 2013: 204] ${ }^{23}$. Owo mgliste zakorzenienie bądź ukorzenienie miałoby być „rezultatem złożonego procesu, w którym znaczącą rolę będą odgrywały siły endogenne” [Haigh 2013: 208] ${ }^{24}$. Można wskazać na kilka wehikułów zmiany obecnych państw narodowych i światowego porządku. W sferze idei wehikułem takim jest promowana i odświeżona w książce idea kosmopolityzmu. W sferze działań jest nim transnarodowość [Haigh 2013: 222] ${ }^{25}$ oraz globalizacja, którą należy promować odgórnie - przez formowanie wspierających ją elit i oddolnie - przez formowanie umysłów mas [Haigh 2013: 199]. Notabene istnieje, zdaniem autora, ścisły związek między globalizacją a działaniem transnarodowym. Dzieje się tak dlatego, że głównym skutkiem globalizacji jest działanie na odległość

22 Wszelako pytaniem pozostaje, czym ono będzie się stawać: „who knows what might be the effect of 350 years of skilled cosmopolitanism under condition of globalization?”.

23 Jak czytamy: „As argued, the Westphalian order is already of necessity giving way to a broadly neomedieval structure of embedded cosmopolitan states".

24 Jak czytamy: „fully embedded cosmopolitan democracy is the end of a complex process in which endogenous forces play a prominent role".

25 „The importance of transnational organization and authority has been evidenced (...) throughout this work". 
zmuszające do wprowadzenia zarządzania transnarodowego (transnational governance) [Haigh 2013: 222] ${ }^{26}$. Ponadto, zmianę państw narodowych i ładu światowego wspierać mają: normy demokracji i praw człowieka, rynki, nauka, racjonalność naukowa i technologia, społeczeństwo obywatelskie, międzynarodowy system prawny, reprodukcja symboliczna, idea postępu [Haigh 2013: 198]. Co ciekawe, roztaczane perspektywy zmierzchu ery państw narodowych, czyli zmierzchu ery westfalskiej znajdują dopełnienie w spostrzeżeniach o dokonującym się na naszych oczach uwiądzie wspólnoty narodowej. Jednym ze wskazanych czynników i symptomów owego uwiądu jest stopniowa utrata „wspólnego kodu komunikacyjnego” [Krzysztofek 2001: 30]. Mimo dużej dozy sceptycyzmu z jaką należy przyjmować zapowiedzi końca ery westfalskiej, również w scenariuszu dopiero co wskazanym, trzeba też zauważyć, że w świecie kosmopolitycznych $\mathrm{z}$ definicji państw nie ma miejsca na pogranicze, jakiekolwiek nie tylko na pogranicze właściwe.

Wobec formułowanych w akademii diagnoz, podobnych opisanej, historyczne pogranicze etniczne przedstawia się już nie tylko jako cenne laboratorium badawcze, lecz także jako wielka wartość. Etnokultura i swoistość mikrosystemu pogranicza, $\mathrm{z}$ istoty niekosmopolityczna, okazuje się godna nie tylko badania, lecz także strzeżenia. Temu służyć może rozpoznawanie i nazywanie obecnych i przyszłych zagrożeń pogranicza.

\section{Bibliografia}

Babiński G. (2001), Pogranicza stare i nowe, [w:] K. Krzysztofek, A. Sadowski (red.), Pogranicza etniczne w Europie, Białystok.

Babiński G. (1997), Pogranicze polsko-ukraińskie, Kraków.

Barber B. (2008), Skonsumowani. Jak rynek psuje dzieci, infantylizuje dorostych i polyka obywateli, Warszawa.

Barber B. (1997), Dżihad kontra McŚwiat, Warszawa.

Haigh S. P. (2013), Future States. From International to Global Political Order, Surrey.

Kłoskowska A. (1983), Socjologia kultury, Warszawa.

26 Jak czytamy: „the chief consequences or effects of globalization is «action at a distance». With ever increasing frequency, decisions made in a given state or region tend to ramify beyond its frontiers", co na przykład sprawia, że podjęta w Niemczech decyzja dotycząca stóp procentowych ma wpływ na zatrudnienie w Grecji, Portugalii czy Włoszech. 
Krzysztofek K. (2001), Pięć refleksji o zmieniającej się naturze pogranicz i wielokulturowości, [w:] K. Krzysztofek, A. Sadowski (red.), Pogranicza etniczne w Europie, Białystok.

Kurzępa J. (2001), Instytucjonalizacja przestępstwa na pograniczu zachodnim w świetle badań, [w:] K. Krzysztofek, A. Sadowski (red.), Pogranicza etniczne w Europie, Białystok.

Lubaś M. (2011), Różnowiercy. Wspótistnienie międzyreligijne w zachodniomacedońskiej wsi, Kraków.

Nowicka E. (1999), Badanie pogranicza. Kilka propozycji metodologicznych, „Pogranicze. Studia Społeczne", t. 7.

Romaniszyn K. (2015), Krótki wykład o utowarowieniu, Kraków.

Romaniszyn K. (2007), Rzecz o pracy i konsumpcji. Analiza antropologiczna, Kraków.

Sadowski A. (2001), Harmonia i konflikty na pograniczach, [w:] K. Krzysztofek, A. Sadowski (red.), Pogranicza etniczne w Europie, Białystok.

Sadowski A. (1992), Pogranicze. Zarys problematyki, „Pogranicze. Studia Społeczne”, t. 1.

Simmel G. (1975), Socjologia, Warszawa.

Szczepański M. (2001), Na peryferiach systemu światowego? Socjologiczna refleksja wokót miejsca pogranicza kulturowego w układzie globalnym, [w:] K. Krzysztofek, A. Sadowski (red.), Pogranicza etniczne w Europie. Harmonia i konflikty, Białystok.

Sumner W. G. (1995), Naturalne sposoby postępowania w gromadzie. Studium socjologicznego znaczenia praktyk życia codziennego, manier, zwyczajów, obyczajów oraz kodeksów moralnych, Warszawa.

Sztompka P. (2005), Socjologia zmian społecznych, Kraków.

Sztompka P. (1991), Teoria stawania się społeczeństwa. Szkic koncepcji, [w:] Przełom i wyzwanie, Pamiętnik VIII Ogólnopolskiego Zjazdu PTS, Warszawa - Toruń.

Turowski J. (1994), Socjologia. Wielkie struktury, Lublin.

Wieruszewska M. (red.) (2007), Tu i tam. Migracje z polskich wsi za granice, Warszawa.

Zenderowski R. (2012), Religia, etnonacjonalizm i tożsamość narodowa: powiąania $i$ modele relacji (ujęcie teoretyczne), [w:] R. Zenderowski (red.), My już jesteśmy zjedzeni... Rola i znaczenie prawosławia w konflikcie etnicznym w Dolinie Pleszewa, Warszawa. 


\section{SUMMARY}

\section{Factors of potential deconstruction of the ethnic borderland}

The paper comprises a theoretical exploration focused upon the ethnic borderland and the potential factors of its decomposition present and active in contemporary world. Namely, attention and discussion had been focused upon peculiarity of ethnic borderland build and maintained by social and neighbourhood relationships between members of numerous local ethnic groups, and its distinction from areas located near the border-line, on the one, and from the social boundaries on the other hand. The argument of this paper is that contemporary further existence of ethnic borderland has been threatened by a number of factors, among them the uniformity caused by cultural globalisation, that is by globally transmitted products of popular culture, by mass emigration from the borderland, by multiculturalism, and by gradual deconstruction of the nation-state.

KEYWORDS: ethnic borderland, border-line, social boundaries, multiculturalism, cultural globalisation, popular culture 